Article

\title{
Educational Services for Intellectual Capital Growth or Transmission of Culture for Transfer of Knowledge-Consumer Satisfaction at St. Petersburg Universities
}

\author{
Nadezhda N. Pokrovskaia ${ }^{1,2, *}$, Marianna Yu. Ababkova ${ }^{1}$ and Denis A. Fedorov ${ }^{2}$ \\ 1 Peter the Great Saint-Petersburg Polytechnic University, St. Petersburg 195251, Russia \\ 2 Herzen State Pedagogical University of Russia, St. Petersburg 191186, Russia \\ * Correspondence: nnp@spbstu.ru or nnp@herzen.spb.ru; Tel.: +7-921-9899-731
}

Received: 19 May 2019; Accepted: 25 June 2019; Published: 15 July 2019

check for updates

\begin{abstract}
Higher education has complex roles in society, the economy, and politics; it helps to transmit culture, transfer knowledge, and develop the personality of citizens. This diversity of roles is confronted with the limited resources that are related to the sources of financing, that is, students and their families, the national government, and local authorities, among others. The discussions related to the role of universities concern the economy of knowledge and the digital tools influencing education. The specific case of St. Petersburg universities simultaneously represents the impact of the deep socio-political transition from Soviet society to the liberal principles of a market economy, including the perception of higher education institutions as service sector companies. The services allowed by universities include research and training; however, from the consumer point of view, universities should create specific value: the increase of the intellectual components of human capital. These complex functions are interconnected. During 2017-2018, a survey in St. Petersburg was organised to ascertain the opinion of students, professors, and employers on the quality of education. The results of the survey demonstrate the impact of the exaggerated implementation of the liberal principles on education, both positive and negative. The positive effect is the renewing of content and innovative training techniques due to competition among universities. The negative impacts include the preference for popular disciplines and the opportunistic behavior of students that lose their passion for acquiring knowledge and choose instead the passive attitude of consumers of a competitive service. They are less interested in the sphere of their studies, in searching for a job, in the interaction with other social and economic actors, and even in the research and education options presented by the universities.
\end{abstract}

Keywords: transfer of knowledge; consumption of knowledge; intellectual capital; consumption society; education

\section{Introduction}

The academic milieu in Russia since the 1990s has been debating the role of the university as a sacred or profane institution, as a truth creator or a service provider. The impact of labor market demands on graduates affects the choice of universities made by students and leads to the implementation of marketing and branding tools for education as a kind of good or service. Low-skilled or unqualified mass work did not require university graduates until the mid-20th century. The increase of the economic role of highly qualified employees was demonstrated by the Leontief paradox, and the studies that followed it in the middle of the 20th century. University choice used to be influenced by personal interests and motivations, but after the second world war, the wider population started 
to make the decision to get a higher education under the pressure of labor market requirements. The strong influence of the market concerned the Russian population, since the market economy transition took place in the mid-1980s and during the dissolution of the Soviet Union in 1991. A quarter of a century later, in 2017-2018, a large survey in St. Petersburg (of students, professors, and employers) demonstrated the return of the pendulum to the compromise between practical factors influencing the choice of higher education and the personal hunger for self-realisation and deepening one's knowledge in the fields of personal motivations and interests, but now with a consumer attitude toward the educational service.

The saturation of markets, including the market for training and educational programs, leads to the necessity of improving customer satisfaction. The consumption of university activities and services for students is based on the knowledge transfer that, paradoxically, can only be efficiently accomplished through the transmission of a culture of research, learning, and knowledge assimilation. Intellectual capital is fostered on the grounds of human capital and the socio-cultural regulation as the fundamental basis for the organisation of the knowledge economy [1-4]. Universities can act as economic agents producing intellectual capital only if they are efficient as social institutions fostering the personal features of graduates [5].

This contradiction between education's roles-to sell information (intellectual assets) and to develop personality [6] — leads to a number of broad questions related to the analysis of the goal setting, which is to precede to the evaluation of consumer satisfaction and the marketing activity of universities.

This paper represents part of a larger study focused on the quality of education. The empirical data collected were investigated to answer the following groups of research questions:

- What are the priorities of learners, teachers, and employers, and what is the structure of the criteria of universities' assessment (questions in Sections Q1-Q3 in Appendix A)?

- Are the behavioral models different among students at different levels of education (bachelor and master's levels) (questions of Section Q4)?

This paper is organised according the classical construction. The initial part (Section 2) introduces the discussion on the ideas of higher educational institutions as subjects of examination. The following parts (Sections 3-5) illustrate methods and results of the conducted empirical investigation. The final part (Section 6) presents further research issues that give the perspectives for the study of the essential educational functions aimed to the society (collective) progress and individuals' (personal) growth.

\section{Discussions on Education as a Social Institution}

Education can be considered from the perspectives of the university as a supplier of educational services, a society or community, a business (which represents its needs in the labor market), or as individuals seeking self-actualisation and personal development.

These four standpoints are investigated within the marketing, economic, sociological, and psychological studies, the results of which are considered within the university's governance.

\subsection{Consumers of Education and Their Needs}

The first question relates to determining the consumers, among whom three essential categories can be distinguished - the customers (families and parents of students), the consumers (learners themselves), and the employers who will implement the competences and skills of the graduates after their university in the value-creation chains as highly skilled and qualified human resources $[7,8]$.

The purchasers buying the educational services are primarily the families of the students, and thus the marketing efforts of universities are highly oriented towards the students' parents. In Russia, the educational services are paid by the students (their families) and by the federal state. Higher education institutions are financed from the state budget, and partly offer commercial education. The endowment funds and business supports for students (ones selected by companies for further employment or those who are already employed) represent only a minor part of the financial resources 
of Russian universities. Therefore, the purchasers are represented by the taxpayers (through the public financing of education) and the students' families who pay for their studies (in the case of commercial programs) and living expenses during the period of study if the learners are not employed and have no income. We can conclude that the essential purchasers are the families of the students who are interested in increasing their human capital-especially their intellectual knowledge and competence, but also their happiness with the self-realization in professional activity.

The consumption of service is realised during the educational process; the groups involved in this learning process are students and professors, which means that the direct consumers are the learners [9] taking part in the lessons, lectures, seminars, etc.; the activities of studying and teaching; and, sometimes, of research or of practical work, at academic labs or at "field" internships in companies, in the forms of presence classroom work or remote learning [10-12], communicating through direct personified interaction with the use of the social media and messengers [13,14], or through de-personified platforms with online courses or material for autonomous learning. The professors are the service personnel for students, in the educational market paradigm.

Finally, the consumption of education results takes place inside business organisations, companies, or establishments that build value creation chains and produce added value for the end customers in different industries and sectors of the economy. The consumers of the fruits of education (of the graduates' human capital) are the employers [15]; the individuals are able to "consume" their human and intellectual capital through jobs in companies, freelance work, projects ("gigs"), and similar employment, or in their own entrepreneurial activity.

This triple consumer satisfaction concept influences the understanding of the quality of educational service. This impact is transparent and direct in the field of the knowledge substance, the content taught: the students as well as their families are interested in the increase of the value of the graduate on the labor market, and the knowledge and competences acquired should meet the anticipated needs of the employers. There are opportunities to apply practical wisdom, which is called "phronesis" (applicable wisdom) [16], that is, "wisdom in accordance with the situation" [17]. Phronesis does not appear from the study of formulas in the textbook, and is developed in the course of real work, because the rules of activity are not always clearly formulated. This reasoning has led to the implementation of the competence approach; the competencies and skills are enumerated in the federal state educational standards that are compulsory for universities in Russia.

However, in several cases, the impact of the diverse interests of the three groups of customers can bear a perverse character; for example, students are interested in paying less effort and attention to the learning process and prefer distraction instead of learning, including entertainment in the classroom (funny lessons are more attractive than rigorous learning). This opportunism will be reflected in less time spent on studying activities and, potentially, choices made by students in favour of less complicated specialties, weaker teaching and easier studying, and more pleasant pastimes and wider leisure activities within educational institutions. The choice of specialty for studying at university is also influenced by the image and reputation of different professions, and the concrete choice of a future career depends on mass media presentations and cultural codes [18].

\subsection{University Performance Assessed through the Growth of Human or Intellectual Capital}

The conceptual approach of "economic imperialism" [19] addresses education from the perspective of micro-economic analysis. According to this approach, the measurement of scarce resources and the results of their use is applied to all aspects of human life $[20,21]$, including education as a transfer of knowledge that is understood as an investment with the purpose of further return in the form of future income [3]. The essential factors to increase the return on investment (ROI) (used as the main indicator of efficiency) of human capital include physical health and intellectual capacity; the latter is formed due to the educational process.

Intellectual capital is usually seen from the point of view of the quantification and transformation of human and intellectual performance into a numerical form that allows managers to calculate the 
indicators of efficiency. The economic analysis of intellectual capital is based on the evaluation of intangible assets as the registered and measured results of creative intellectual activity, such as patents, brand value, good will, and relational and structural capital [22-26]. Universities are perceived as one of the triple helix players-research and educational institutions are responsible for knowledge production (in the form of both intangible assets and of graduates' competencies and abilities to solve professional tasks) for business purposes with governmental support $[27,28]$. According to this approach, the efficiency of the university as a social-economic institution can be assessed through (i) the intellectual property produced (e.g., number of patents and licenses registered) and (ii) the increased income of the graduates with the human capital due to the education received. The first group is analysed in studies on intellectual capital; scholars propose the use of different methods to assess the value-added intellectual coefficient (VAIC) [29-31], the intellectual capital maturity model (ICMM) [32], etc. The core role of the relations that are built through the interactions is investigated in economics and management research, from marketing [33] to contracting [34]. Tacit knowledge is formalised by brainpower, taking the commitment of the knowledge bearers into account [35-37].

\subsection{Institutions Reproducing Society—Balance between Conservative and Innovative Roles}

Another group of questions relates to society as an agent that uses universities as institutions that reproduce society. The evolution of societal structures is a long-term process that needs both change and tradition. The pragmatic approach to the transmission of culture and transfer of knowledge as a part of social regulation and governance represents the new requirements of the information society to the university as a core institution able to reproduce the essential features identifying a society and to adapt to the accelerated post-modernity dynamics [38]. From this standpoint, the adaptability of universities as social institutions is limited by the process of the identification of societies, the necessity to save and conserve the central elements of the civilisation and values scales representing each society within the societal diversity of mankind. According to this approach, education serves society and maintains its identity.

The interesting example of such an evolution is given with the Soviet Union and Russian society. Since the Union of the Soviet Socialist Republics (USSR) was dissolved on 26 Dec 1991, the education system has had to produce a very fast answer to questions of identity. At the same time, the practical realisation of activities in the science and education spheres had very low financing that led to a rapid loss of trust and a collapse of prestige among the populace who began viewing their education as "useless" knowledge. The sharp rise of crime in Russia in the 1990s provoked the state of "bespredel" (absence of limits [39], lawlessness, arbitrariness, complete rejection of any and all rules [40]) that forced the whole population of Russia to become familiar with pragmatic market rules that impose criteria related to future economic return on investing time and financial cost into education as a component of human capital and intellectual assets.

On the level of society and community, schools had to reproduce the values of traditional Russian and modern Soviet society-within the environment of the post-modern consumption society and liberal ideology. This societal shift has been reflected by the education sphere, and the confusion has appeared in the aims and methods of this sphere. The "bespredel" has influenced both the field of substantial knowledge and of teaching approaches and techniques. Multiple reforms of education constantly transformed the content and the organisation of learning. The appearance of private high and higher education schools and universities met the communities' need for popular specialties' diplomas and certificates-the documents necessary for some positions without regarding the real substance of the knowledge and skills required. This bureaucratisation and formalisation of educational activities represented the institutional changes that had taken place.

On the level of the organisation of knowledge transfer activity, a practical concern for universities is the degree of change that is reasonable to introduce—courses on new technologies, innovative teaching technologies, new equipment for neuron communication and biological feedback (presenting the psycho-physiological parameters of cognitive processes), chemical or electro-physical intervention that 
stimulates thinking process, etc. The problem of the frontier for the development of cognitive process relates to the societal concept of "human" and potential options for its expansion and enhancement with any kind of up-to-date technologies or within ethical or cultural borders.

\subsection{Measuring the Miracle of Knowledge Creation}

The fourth group of questions examines the attitude toward universities as either sacred or profane institutions. The cognition process, including discovery, research, and invention, has yet to be completely revealed by neuro-physiologists or psychologists; it represents a kind of mystery-a magic miracle of creation. Talented people form "intellectual capital", but at the same time their "production" process is not clearly manageable [41]. The governing actors can invest in human capital, but still cannot be certain of obtaining any return.

The global education market presents a wide range of training and learning opportunities at attractive prices. Competition between the different kinds of educational institutions concerns universities as sellers of a specific type of service. The service approach has been applied since the creation of the first universities in Europe-the Salerno medical school (9th century) and Bologna canon and civil law university (11th century). European civilisation oriented knowledge to maintain and develop the pragmatic tasks of professional activities. In Eastern civilisations, the social position of the education system was related to tradition, to social integration, and to the political reasons for the institution (i.e., promulgating grammar, language, ideology, or law [42-44] as a socio-cultural basis for common actions). Knowledge is perceived as sacred, in contrast to the profane skills and abilities. The concept of "sacred" derives from the Latin sacer, and refers to God and consecration, the protected part of reality; the term "profane" refers to things that were extracted from the temple for human use. E. Durkheim contrasted these two opposing classes, describing the "beliefs, myths, dogmas, and legends ... representations or systems of representation that express the nature of sacred things, the virtues and powers attributed to them" $[45,46]$ (p. 34). This discontinuity between the world and the things found in it separates the profane from the sacred [47] (p. 111).

These two traditions were confronted in Russia in 1990s after the collapse of the previous society, with a basically meritocratic organisation, facing the socio-cultural vacuum.

In the 1990s, knowledge became useless and the educational institutions lost the people's esteem and respect, because the criminal situation produced an unpredictable environment where long-term investment in capital (physical, human, and intellectual) was not justified economically. The reforms of higher education worsened the situation, making final higher education testing the essential goal of schooling, rupturing the strong traditions of the Soviet school and decreasing primary education from the difficult but respected process of knowledge acquisition [48] to the routine standard fulfilment of bureaucratic rules and procedures.

Scientific metrics and quantitative assessment are based on the hypothesis that it is possible to measure the quality of educational and research activity. University education involves research because of the logical reasoning within the wide chain of knowledge-from the production of knowledge (research) through its transfer and onto the consumption of knowledge (commercial use). The University 4.0 is discussed essentially as a "university-corporation" pipeline (see [49]) that includes all the stages of the knowledge economy: fundamental research and invention, applied interpretation and design, development, and improvement and implementation of attained knowledge and mass commercialisation.

The place of the educational process within this chain is determined by the involvement of students in all stages, which theoretically helps to simultaneously achieve the realisation of the processes of culture transmission and knowledge transfer. The essential problem relates to students' involvement because of fragmented perception of and new approaches to the treatment of information overload. Cognitive practices are mutating from clip-conscience to click-conscience; the production of new knowledge is limited by the disruptive technologies that cause creative destruction [50]. Accelerated disruptive innovations lead to the closure of firms and loss of jobs (while appearing to create new 
professions and employment). Short-term reasoning and post-modern reflexivity and subjective attitudes [51] form choices, making behavior models that are not oriented toward investment in intellectual capital but toward solving situational and up-to-the-minute tasks, avoiding any significant effort and resource expenses and preferring to "swallow" or "ingest" the knowledge given-to absorb instead of create.

\subsection{Analysis of Cognition Behavior to Improve Universities' Governance}

The societal aim of education as a social institution consists of the reproduction of a concrete society and in the production of new knowledge on the basis of the previously accumulated data and information, understanding, and meaning. Forming a citizen's personality (a community and society member) requires resources-first of all, for finance that could help the existence of institutions to realise this purpose. If universities' essential purpose is to embody societal aims, society should finance their functioning through centralised planning and tax redistribution as a budgetary source.

The destroyed Soviet planned economy tradition was replaced with illusions of an omnipotent market mechanism. However, the liberal approach is also restricted, because, as the 1990s-2010s demonstrated in Russia, the total transformation of universities into profit-driven companies demonstrates several problems, such as

- Weakening quality of education in less-popular disciplines (i.e., for engineering, chemistry, physics, and medicine);

- A glut of specialists for demanded professions (i.e., management, marketing, finance, and law);

- Generally low competences and knowledge of the "input" (high-school students coming to universities) and, by consequence, of the "output" (graduates);

- Unwillingness of students to learn because "they have paid and should be given a final and packaged product", gifted with a "wrapped" knowledge, instead of training competences and acquiring skills.

These perverse effects of the market on a public good such as education require discussion in society as whole and in the educational and governance community in particular.

This article considers the process of education as a choice made by a university of the positioning upon an axis of this dichotomy. Different combinations are possible to ensure an internal "Socratic" process of personal knowledge formation (teaching to learn) and to satisfy different needs and interests of the diverse societal and economic agents involved in the process of investment in intellectual capital. From this point of view, this paper examines the results of a survey realised in St. Petersburg universities related to the quality of educational services in 2017-2018 as the empirical basis for understanding the features of cognition for the better governance of higher education.

\section{Materials and Methods}

Our research of consumers' satisfaction included samples of students $(\mathrm{n}=1556)$, professors $(n=234)$, and employers $(n=286)$. The sample details are presented in Tables 1-3.

Table 1. Sample of the students surveyed.

\begin{tabular}{ccc}
\hline Level of Higher Education & Public & Private $^{\mathbf{1}}$ \\
\hline Bachelor & 801 & 514 \\
Master's & 190 & 51 \\
\hline
\end{tabular}

${ }^{1}$ At private universities or at commercial programs in public universities. 
Table 2. Sample of the professors and administrative personnel of the universities surveyed.

\begin{tabular}{ccc}
\hline Position & Public $^{\mathbf{1}}$ & Private $^{\mathbf{2}}$ \\
\hline Professors & 29 & 4 \\
Associate Professors, senior teachers, and assistants & 127 & 21 \\
Vice-Rectors, department heads & 34 & 7 \\
\hline${ }^{1}$ Employees of the state- or city-owned universities. ${ }^{2}$ Employees of private universities.
\end{tabular}

Table 3. Sample of the employers' representatives surveyed.

\begin{tabular}{ccc}
\hline Sector & Public $^{\mathbf{1}}$ & Private \\
\hline Industrial enterprises & 150 & 30 \\
Service sector & 45 & 61 \\
\hline 1 & Public organisations and mixed-ownership companies with the state as the primary shareholder.
\end{tabular}

The sample (Table 1) exactly represented the whole student population of St. Petersburg, because the sampling procedure was based on the statistics of the St. Petersburg City Administration, Committee for Science and Higher Education Schools.

In the sample of universities' teaching and administrative staff (Table 2), 15.1\% had a Doctoral degree of Science (the Russian system requires two theses be defended; the first thesis gives the analogue of a PhD, the second one earns the degree of a Doctor of Science), and $68.1 \%$ were PhDs (called "candidates of science" in Russian-the same title for medical, technical and social sciences).

Employers' opinions were investigated according to their positions inside organisations (Table 3). The people interviewed occupied positions of mid-level managers involved in the search and selection of candidates for job positions from the standpoint of consumers of graduates' knowledge, competences, skills, and capacities. They are responsible for motivating employees and applying their highly skilled labor in organisational and business processes.

The representation of industries and service sector organisations reflects the structure of the St. Petersburg economy, which inherited the Russian Empire's and Soviet period's high ratio of industrial plants and production and service enterprises that were organised for technical support-especially for mechanical construction and military defence industrial capacities, including the ship-building industry due to the costal position of the city. Among the service companies there are museums, hotels, restaurants, libraries, clinics, and banking institutions.

The significant differences between the public and private organisations were not revealed, while the industrial and service companies demonstrated a slight differentiation in questions regarding the connection between internship and employment (industrial enterprises invited students on the basis of the preliminary internships twice as often) and on the impact of higher education on the options on the labor market (the industrial respondents evaluated the employment perspectives of the graduates at 6.440 points and the service sector at 5.286, of a maximum 10 points).

The survey was fulfilled on the basis of a questionnaire that was elaborated for longitudinal research in 2015 and reproduced in 2017-2018 for this research, with minor changes. Questions regarding digital learning tools and digital economy perspectives were introduced, and were verified in a pilot survey in September-October 2017.

The most basic research question was related to the improvement of education quality, but to answer this request from the city administration it was necessary to understand the essential roles of the universities: the quality of task fulfilment and goal achievement depends on the particular tasks and goals being considered. From the perspective of the funding institution (i.e., the St. Petersburg authorities), the qualities were presented with the equipment of the universities and the satisfaction of the employers, but we are attempting to demonstrate that the goal of higher education is broader than classrooms being equipped with computers and the assessment of employers, especially when 
considering the specific structure of the city's economy over the past two centuries. The path to dependence is expressed in St. Petersburg by the high level of labor market requirements for engineers and technical specialists, with a weaker interest in social and human specialities.

The essential research question presented in this paper relates to the analysis of education as a complex set of diverse functions that determine the parameters of the quality of assessment.

The pragmatic objectives and societal values of education are both considered to be the fundamental reasons for the existence of universities. The methodology of this research attempted to account for the humanistic (constituting the forming of the personality) and the pragmatic (constituting investment in intellectual capital) approaches.

The questionnaire included the issues of infrastructure and of organising the learning process, the factors influencing the students' choice of university, the reputation of universities, and the prospective possibilities of and reasons for employment. The content of the education process and its results are societal, technological, and cultural: the information society, the consumption society, and the digital economy orient education towards profit-driven business to obtain rent from investment (especially investments in human capital and, more broadly, in intellectual capital). The labor market approach determines the assessment of the quality of education as a measure of employer readiness to hire graduates and pay for their contribution in the work place (level of the graduates' wage). The students and their families (i.e., direct consumers and purchasers of the educational activities) consider higher education to be a tool for identification and positioning within the social structure-individuals take their place in the social hierarchy due to the possibility for career climbing and earning money.

The substantial elements of education are strictly determined within Russian Federal educational standards: the list of disciplines taught; the schedule of practical works, internships, seminars, and research sessions; and the texts and examination procedures for the four years of bachelor studies or two years of master's programs are fixed by the university department and are registered in the documents that are to be approved and confirmed almost a year before the start date, usually during the autumn of the year previous to the enrolment of the students to the program. This means that the content taught to students is fixed before their studies begin. However, the form of teaching is subject to regulations that are much less strict, and hence the survey of the education quality in the St. Petersburg universities was focused more on the infrastructure and learning environment than on the content, which is controlled and managed not by universities but by the Ministry of Higher Education and Science of the Russian Federation.

The questionnaire was structured along the following four perspectives:

- The reasons for choosing an educational institution (Section Q1);

- The external characteristics of the university on the market (reputation) and internal indicators of the quality of the conditions surrounding the studying process (organisation of dormitories, restaurants, equipment of classrooms and buildings, information technologies and computing techniques, and physical and electronic libraries), including the behavioral parameters of the actors of learning and teaching (Section Q2);

- Quality of the education's results, learning outcomes, and employment prospects (Section Q3);

- Availability and access to the extra activities at the university, such as conferences and round tables, additional lectures by invited professors and employers, master's classes, exhibitions, meetings with business representatives and visits from enterprises, sports, arts, job fairs, and international activities (Section Q4).

Section $B$ concerns the demographic data of the respondents and information regarding the level and characteristics of study (Appendix A). 


\section{Results}

The results of the survey demonstrated significant differences in assessments between the groups of respondents-the students, professors, and employers.

\subsection{Learning Outcome and Employment Prospects for the Measurement of Education Quality}

The general evaluation of employment perspectives, as well as of learning outcome, showed similar results for bachelor students and employers, with higher values given by the master's students and university staff surveyed. The answers are presented to the question "How can you evaluate the essential results of education?" in Figure 1.

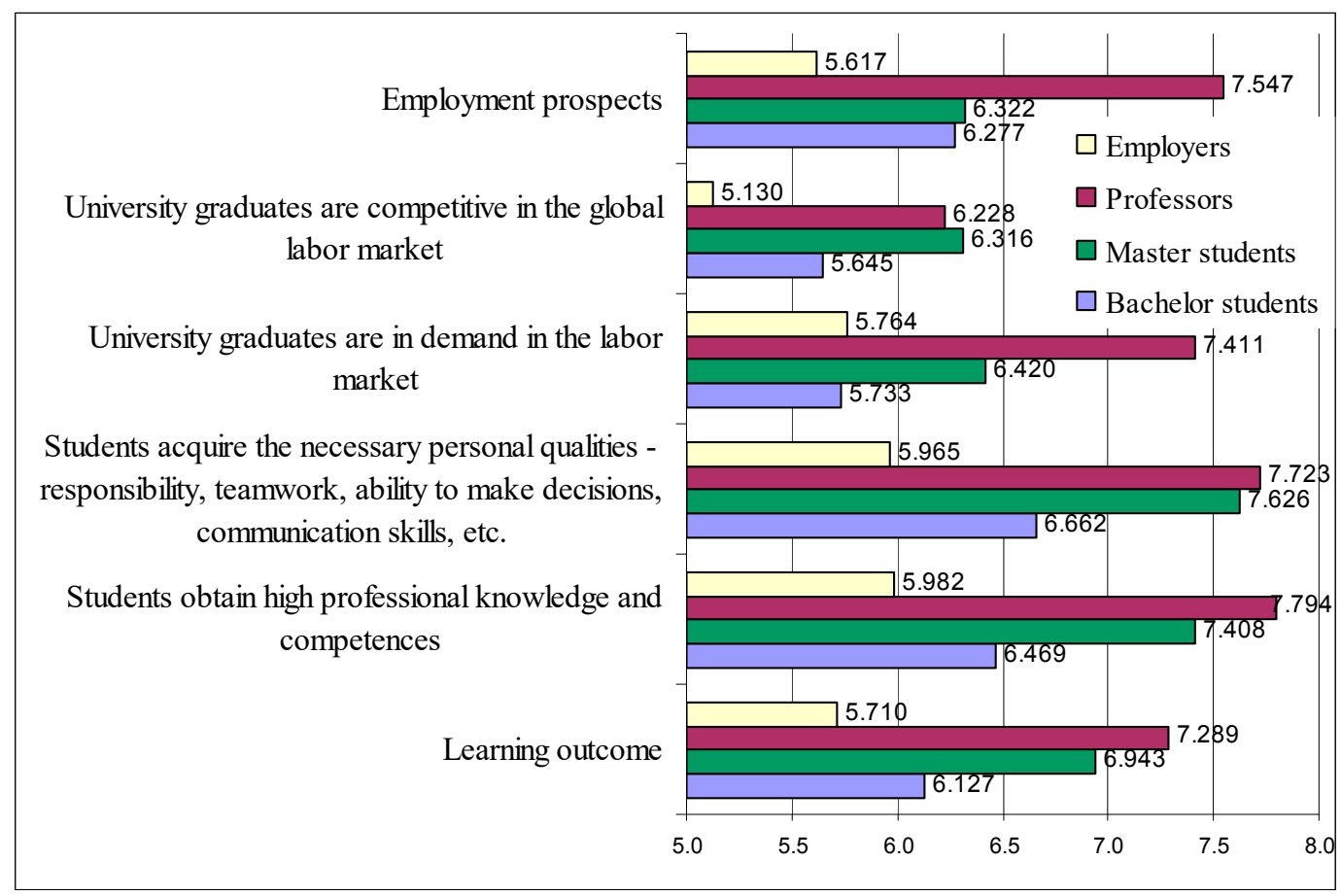

Figure 1. Survey answers on the evaluation of the employment prospects, education results, and learning outcome given by groups of respondents according to a 10-point scale (with 1 being the minimal assessment and 10 the maximum assessment).

The results show that the professors gave the highest assessment rates regarding employment prospects and education results. Their assessments were higher than the opinions given by all other groups, except for the evaluation of competitiveness in the global labor market, where the master's students gave higher rates (6.316 points vs. 6.228 as rated by professors). These results reveal two tendencies - the over-estimations and illusions that professors have about the results of their own work at universities, and the under-estimation of both local employers and bachelor students of the possibilities in the global labor market; global business seems to be more open to master's students.

The evaluations of the parameters of education quality are presented in Figure 2 (as the answer to the statement "Evaluate the different elements of education quality among the listed below, 1 point-the lowest mark, 10 points-the highest evaluation"). 
Teachers are interested and available for consultation

Students are autonomous and independently write final papers

The Internet communication and the use of digital technologies are intensive

The educational process is rich and interesting

The teachers use interactive forms of learning - case study, games, etc.

Teachers give clear and accessible explanations with good scientific base

University teachers have high level of the professionalism

The given theoretical knowledge and practical skills are sufficient

The knowledge given at the Univeristy is applicable in practice

The knowledge given at the Univeristy is relevant and modern

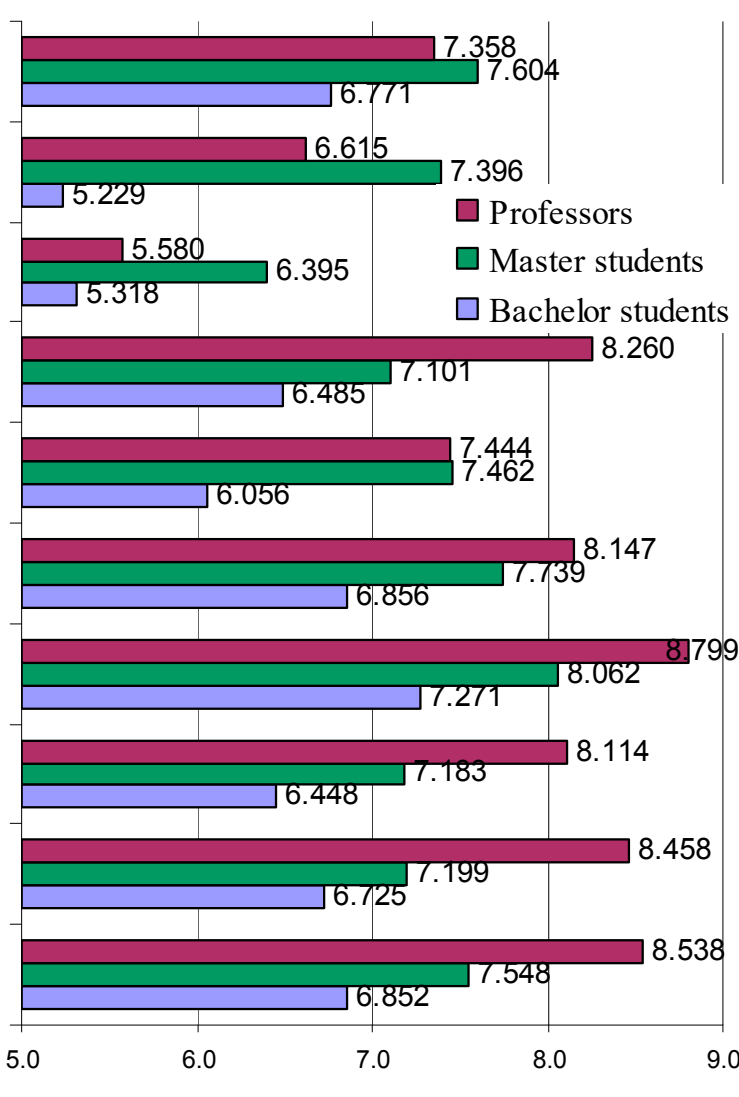

Figure 2. Assessments given by groups of respondents regarding the educational process, according to a 10-point scale (with 1 being the minimal assessment and 10 the maximum assessment).

More than half of the ten learning process parameters were assessed lower by the learners than by the teachers. The students-more specifically, the master's students-gave higher assessments of 4 of 10 features of the educational process that were asked:

- The interest of teachers in helping learners, maintaining the studying process, and the availability of professors for consultation (7.604 pts given by master's students vs. 7.358 pts in the professors' evaluation);

- The autonomy of preparing the final qualifying works, master's theses for master's students (7.396 pts vs. the 6.615 pts given by professors);

- The internet, digital technologies, and social media used in the educational process (6.395 pts vs. 5.580 pts in the professors' evaluation);

- The use of interactive forms of education (e.g., case studies, games) (7.462 pts by master's students vs. 7.444 pts by professors).

At the same time, all the assessments of bachelor students were lower than the evaluations of master's students, who were several years older and usually had work experience. This remark concerns the differences of factors and criteria for the choice of university and educational program. It should be mentioned that among the opinions of the representatives of the university faculties surveyed, the factor of autonomy and independence for the fulfilment of certification work by students under the scientific guidance of teachers was low; the score was 6.615 points out of the maximum 10 . The problem with the autonomy in carrying out certification work and of the abuse of the supervisors' help has cultural roots. In Western universities and in double-degree educational programs, academic supervisors take part practically only in the final assessment of the work submitted by the student. Nevertheless, this rate shows the lack of interest and active attitude of the students even towards their final graduating works. 


\subsection{Reasons for the Choice Made between Universities}

The students of bachelor and master programs were asked about the reasons for their decision to study at a concrete university. The essential factors of the selection are presented in the diagram in Figure 3 (the statement was "Please choose the most pertinent and important reasons among those listed below that influenced your choice of higher education institution.").

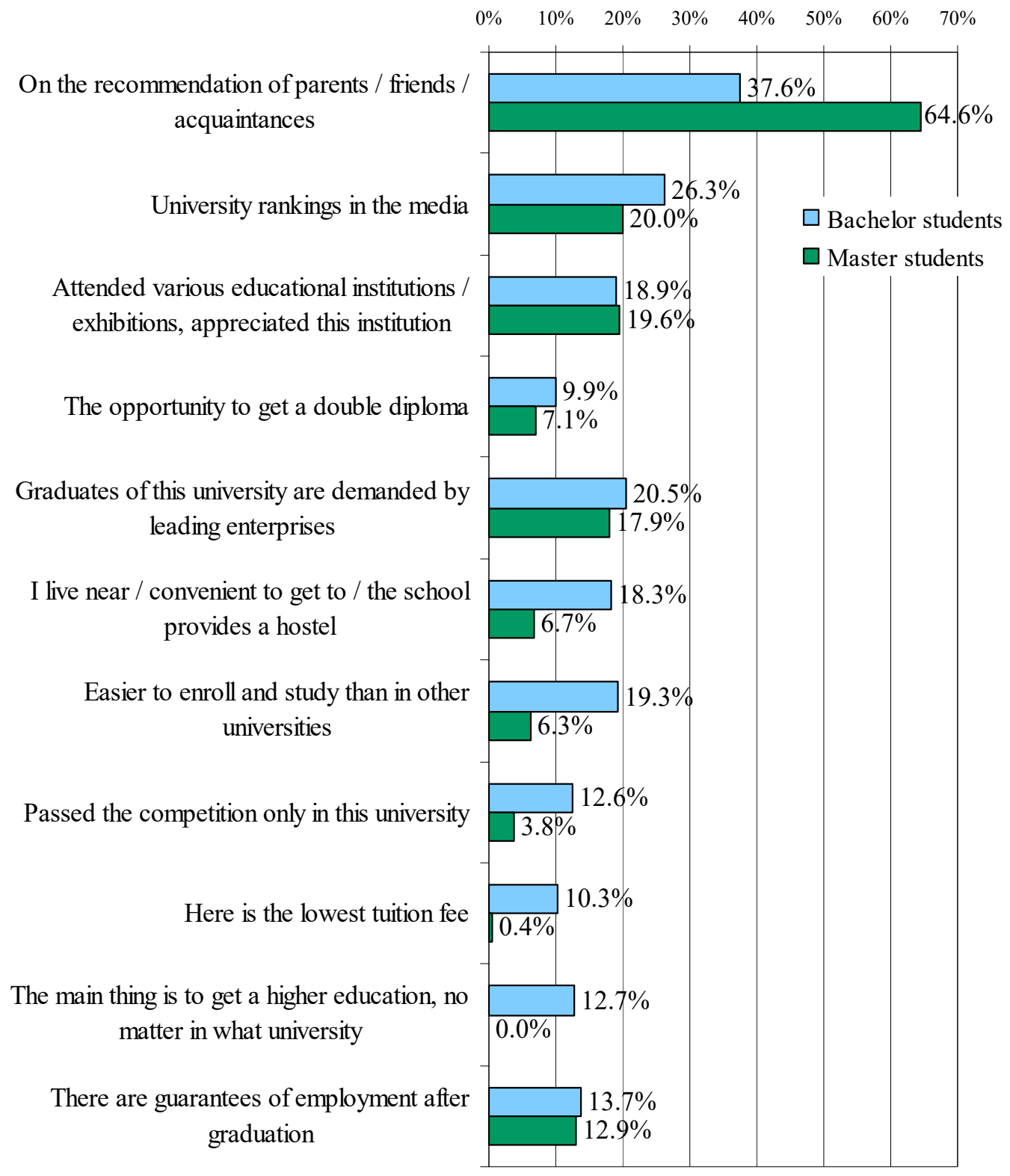

Figure 3. The reasons and criteria for the choice of university made by bachelor and master's students (in terms of the percent of the number of respondents in each group).

The master's students made their choice of university and educational program on a more conscious basis:

- The master's students accumulated more advice and reviews from their confidantes, relatives, and friends ( $64.6 \%$ vs. $37.6 \%$ of bachelor students);

- They attended different events at the universities and the exhibitions of educational services (19.6\% vs. $18.9 \%)$. 
At the same time, the bachelor students followed the more pragmatic criteria for higher education institution choice, as follows:

- Bachelor students more often than master's had analysed the ranking of the university in the media ( $26.3 \%$ of bachelors vs. $20.0 \%$ of master's);

- Bachelor students tried to guess if employers would appreciate the diploma of the concrete university and chose their higher education institution according the demand from enterprises ( $20.5 \%$ vs. $17.9 \%)$;

- They chose universities where it was easier to enrol and study than at other higher education institutions ( $19.3 \%$ vs. $6.3 \%)$;

- A comfortable location of the university was the most significant factor in the choice made ( $18.3 \%$ vs. $6.7 \%)$;

- They had tried several universities but passed the competition only in this one, no matter which specialty $(12.6 \%$ vs. $3.6 \%)$;

- The tuition fee played the decisive role (10.3\% vs. $0.4 \%)$;

- Factually, it did not matter which university, the most important goal was to get any kind of higher education diploma ( $12.7 \%$ vs. $0.0 \%)$.

There were also answers that were quite close for both bachelor and master's students, such as the preference for potential employment options ("there are guarantees of employment after graduation" from the chosen university-13.7\% of respondents among bachelor students and $12.9 \%$ among master's) or the opportunity to get a double diploma of a Russian and a foreign higher education school $(9.9 \%$ of bachelor and $7.1 \%$ of master's students).

These results indicate the levels of conscientiousness of the choice made by students between the different educational prospects on the market of training at the levels of bachelor and master studies.

\subsection{Interest in Employment}

In the concept of education as investment in human capital, employment represents the final result of the educational process. However, paradoxically, students seemed to be the least-interested and least-informed group about the options of finding jobs through the institutional and organisational help from their university (see Figure 4) (the question was "How is graduate employment assistance organized at your university?").

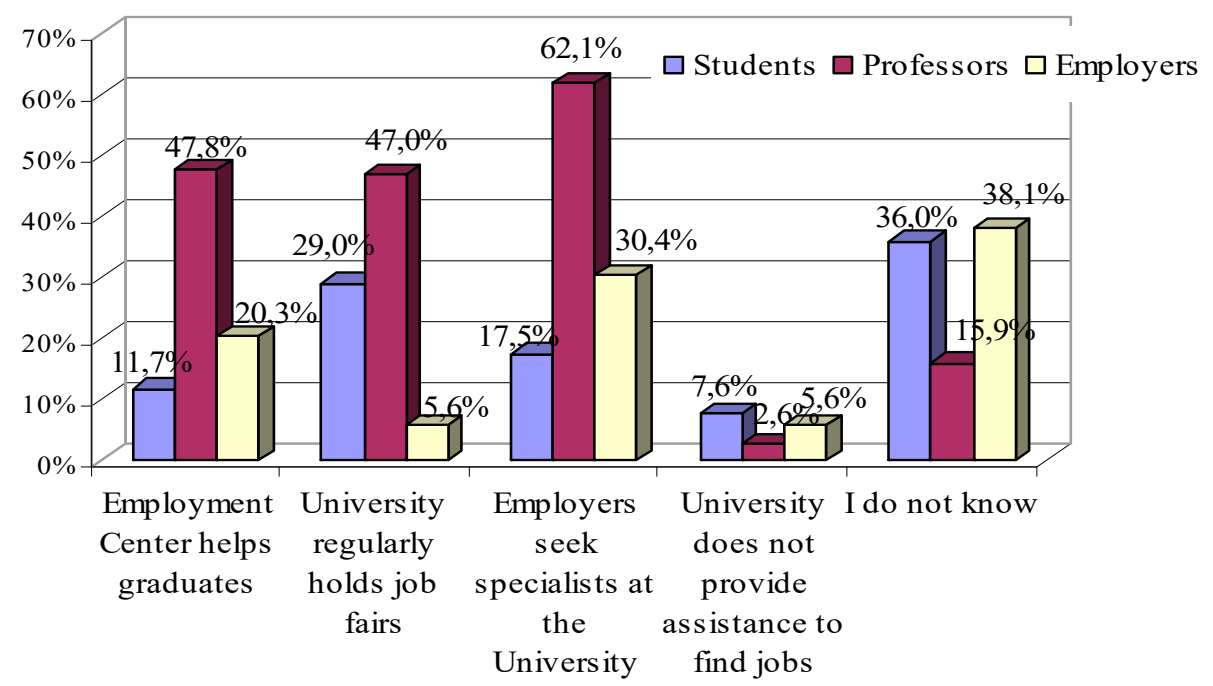

Figure 4. The assessments given by respondents regarding their university's assistance in the employment of graduates (in terms of percent of the number of respondents in each group). 
The university students had less information about employment centres than the professors, and even had less information than the employers. They were less aware of job fairs and exhibitions organised by the university and knew very little about the demands of the employers for university graduates. For example, $30.4 \%$ of the employers surveyed answered that they usually seek candidates to fill vacancies at universities, but only $17.5 \%$ of students knew about this employer activity and could use this knowledge to potentially find a job. The ignorance of the employers about the possibilities of universities' assistance in employment is logically explained by the fact that the employers are not integrated in the higher education institutions' life (38.1\% answered that they did not know if the universities help students to find jobs). The lack of awareness demonstrated by students in this area ( $36.0 \%$ of students answered that they did not know about universities' employment assistance) is typical for a passive position on the labor market, where students are waiting to be found and chosen by an employer.

\subsection{Interest in Research}

A similar lack of interest was fixed towards research activities within universities. The professors are obviously highly involved in all kinds of the academic activities and research events, while the students were less aware and less interested in taking part in research and educational events (see Figure 5; the question was "Do you know if your university holds lectures at school for invited teachers, representatives from employers, well-known media people, thematic conferences, exhibitions, master's classes, and job fairs?").

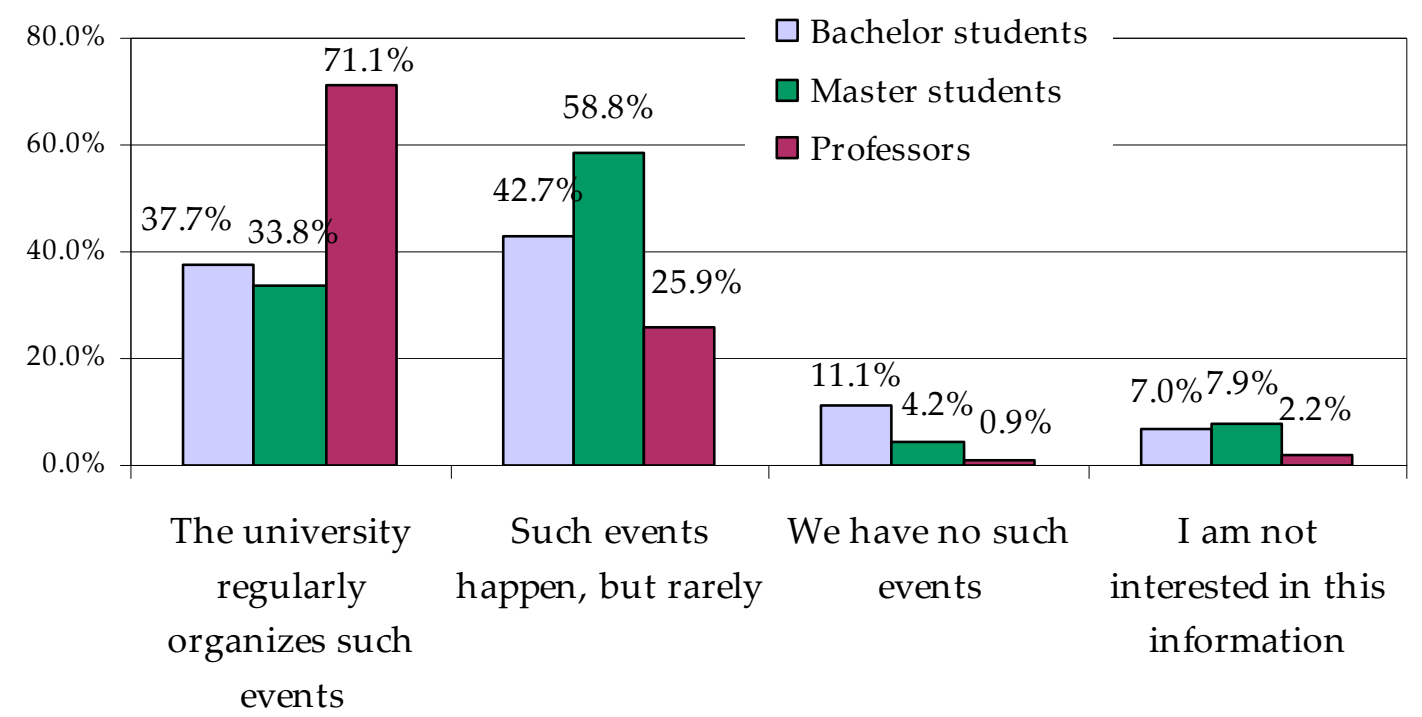

Figure 5. The distribution of the degree of interest in the scientific activities in the university (in terms of percent of the number of respondents in each group).

Overall, $18.1 \%$ of bachelor students and $12.1 \%$ of master's students were not informed or not interested in events that could permit them to participate in research and educational activities outside of the standard schedule of their course. It is interesting that $97 \%$ of professors answered that their university organises research and educational events regularly $(71.1 \%)$ or from time to time $(25.9 \%)$, but among the bachelor students only $80.4 \%$ knew about this activity $(37.7 \%$ of them saying that there were regular events and $42.7 \%$ rated them as rare occurrences).

The master's students seemed to have more determined attitudes and were better informed about these kinds of university activities-92.5\% knew about these events ( $33.8 \%$ answered that these events are regularly organised and $58.8 \%$ that the events happen rarely). 
This revealed the students' ignorance or insufficient awareness about professional, educational, and research activities and events at the university, in contrast with the youth internet activity [52], social media [53], and networking [54,55].

\subsection{Interest in the International Activities of the Universities}

Bachelor students also showed a lack of interest in the different kinds of international activities within the universities. The professors, obviously, are highly involved in all kinds of the academic activities and research events; meanwhile, according to the results obtained, the undergraduates are less aware of any kind of additional university activities, they are less interested in the possibility to take part in local or international research and educational events, e.g., only $9.0 \%$ of the bachelor students and $5.0 \%$ of master's students knew about the European diploma supplement that has been compulsorily delivered by request in all Russian universities since 2012, see Figures 6 and 7 .

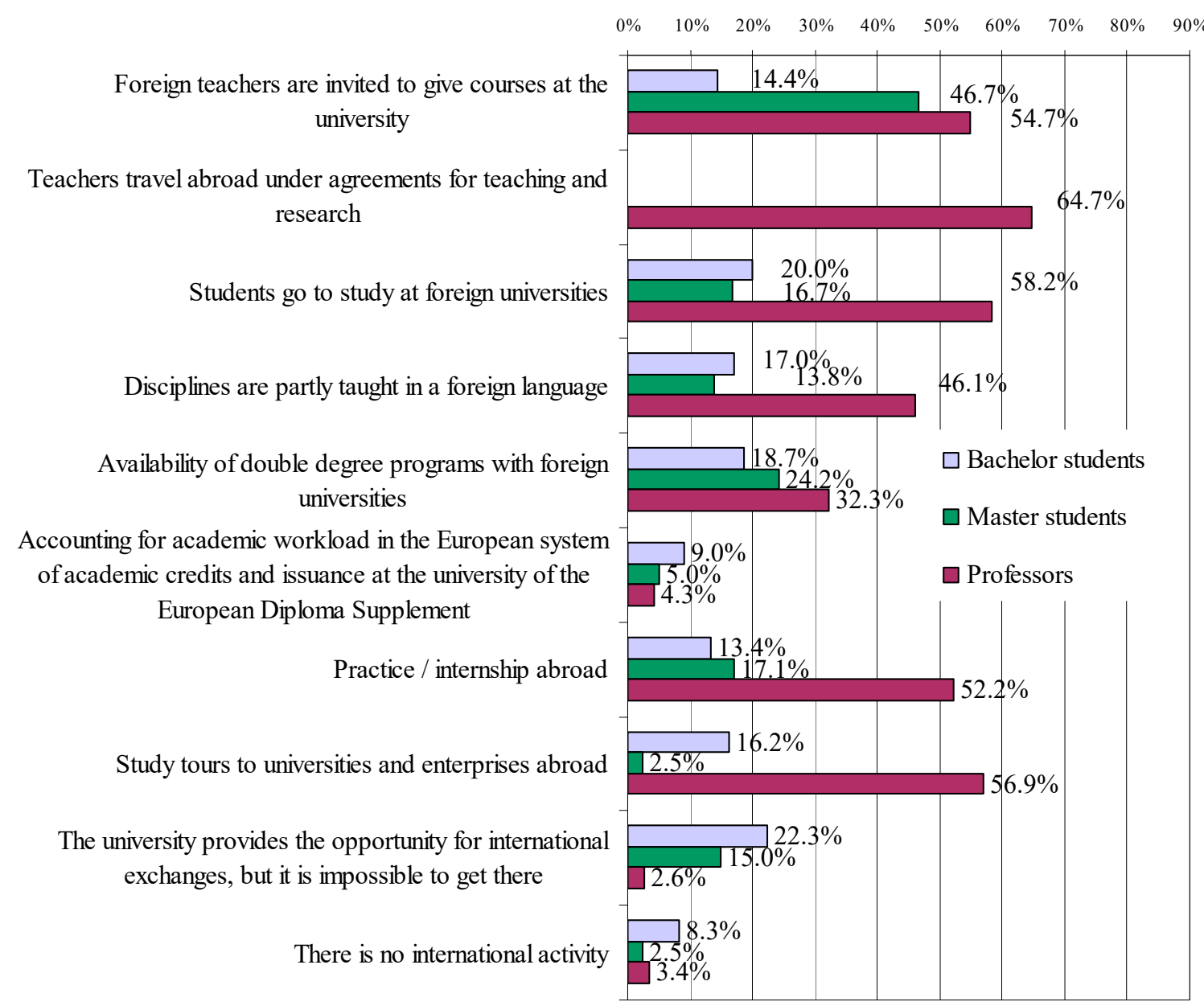

Figure 6. The participation of students and professors in international activities of the university (in terms of percent of the number of respondents in each group).

The global economy is the environment for the professional self-realisation of students [56], but again the professors were well informed about the different kinds of cross-border activities organised at their respective universities, while more than a half of bachelor students (52.1\%) were not sure that they needed to take part in international activities or did not want to. 


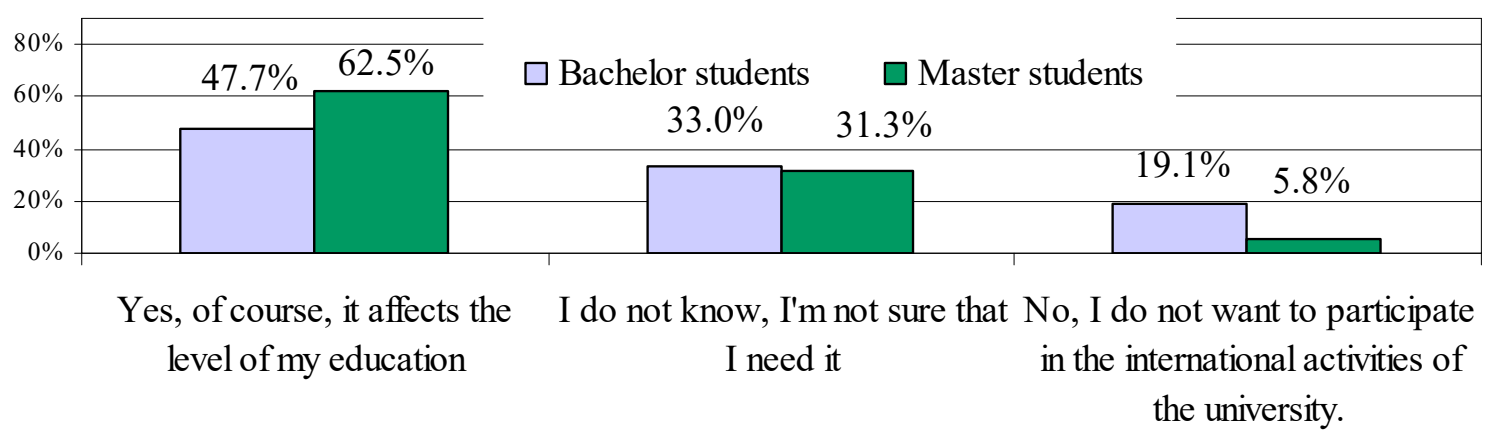

Figure 7. Distribution of the degree of interest in the international activities of the university (in terms of percent of the number of respondents in each group).

\section{Discussion}

This survey was built as quantitative research that allowed us to collect data for the purpose of diagnosing the narrow field of research, the quality of the environment, and infrastructure within institutions of higher education. At the same time, the gathered appraisals show the trends of university functioning in the new consumer society, facing the reality of information overload and scarcity of motivation; digital access and availability of information; and lack of will to analyse or take part in learning, research, or professional activities.

Bachelor students deeply differ from master's students, who invest in their intellectual capital, while bachelor programs' students foster their human and social capital. The structural and consumer capitals (as the components of the intellectual capital) could be presented in the format of integration into professional community and the improvement of reputation ("ego-marketing" or "ego-branding" with portfolio enrichment), but few students demonstrated interest in this.

The results demonstrate the opportunistic behavior of students, not only towards the families who pay for the studies but also towards the employers who will be the final consumers of the skills and competences acquired by the graduates. Moreover, students were certain that jobs would "find them", and they were not interested in searching for employment.

Apart from the rating of the St. Petersburg universities, this study revealed three phenomena causing the authors to examine the results from a societal point of view. This survey can be analyzed within the grid of the information society and of the generation theory; education is considered as the foundation of the construction of an innovative economy of knowledge. The overload of information leads to a consumption-based approach to education.

The first feature of the students that was discovered was the absence of will to take responsibility for their choices: at the bachelor level the selection criteria did not reflect personal interests. The students followed the advice of friends and relatives, the media, and even chose their university according to location. The vocational factor seems to have lost the central role in university enrollment decision making. Their chosen path in higher education did not seem to be directly connected to their future professional path and life-long activities.

The second tendency was the unwillingness to understand the interlocutor. Students taking part in an interaction seemed to avoid any effort to meet with mutual interests, to try and discover problems and tasks, and to propose solutions. They were not informed about the criteria of employers or the requirements of professors, and did not have an awareness of the options to improve their results or enhance their positions. The most important remark is that the students ignored the open possibilities for research, international programs, and employment fairs (i.e., exhibitions of jobs and fairs organised with companies presenting vacancies). The students perceived their own interests, motivations, desires, and comforts as determinant of their interactions, as if the other side did not represent autonomous agents. The bachelor students deeply differed in their behavior from the master's students, who were able to consider the needs and motivations of professors, employers, and administrative personnel of the university. The bachelor students behaved with little regard for the 
potential results of communication; they did not ask about the interests and values from the standpoint of the other side (i.e., teachers, employers). For example, the students did not know (36\%) whether the university provided employment assistance.

The third conclusion relates to the consumer perception of educational services-students wanted knowledge to be given but they did not want to "take knowledge", to make an effort, and to implement an active position in order to acquire knowledge and competences. Students got used to maximally satisfying their needs, as products and services (i.e., educational programs, teaching) are to be imposed on consumers in all possible ways (similar to advertising information in all forms of contextual communication; targeted communication; banner and sales promotion; other advertising through smart-phones and computers, social media, and smart devices everywhere). This habit of taking the passive position as an object of advertising is represented in the behavior of a learner who does not learn but who waits to be taught. The identification of future needs and the formation of the standards of the consumption of educational services considering the specifics of the students' cognitive processes allows scholars and teachers to update and improve their tools of knowledge management in educational organisations and rethink the modern position of the university, which is not only balancing roles between a truth creator and a services' provider but is actively forming a new paradigm for the digital economy of knowledge.

\section{Conclusions}

The results obtained from this theoretical analysis and empirical investigation meet the requirements of both groups of research questions: the system of priorities as the criteria of universities' assessment (presented ex ante as reasons for the choice of educational institution to enrol, and ex post as an evaluation of the quality of the education process) as well as the behavioral models of students represent the elements of opportunism and consumer behavior in saturated markets, including passive position and lack of motivation.

The analysis of the literature demonstrates a lack of sufficient references to understand and argue the universities' functions within the society of knowledge and a digital economy that changes the relations between actors of human capital growth on different layers-from the economic logic of investment in intellectual capital to the cognition processes that need support, frameworks, and motivation. The economic consequences (efficiency of intellectual capital growth) depend on deeper changes of cognitive processes. Cognition is the core element of human growth and human society's evolution, but in the context of a saturated economy, the cognitive processes are not imposed on humans because they are not necessary for survival: if needs are satisfied, human beings are no longer forced to think and improve their connection with reality; people are able to survive without understanding or reasoning, and creative intelligence or the analysis of facts and data become a matter of choice. Digital tools help to avoid any intellectual effort. This problem is reflected in this paper as a quantitative evaluation of students' commitment and involvement in the learning process.

The economy of knowledge fosters the trend to digitize and connect all the processes and phenomena [53], to transform all the components of life into the computable form, and to introduce all the interactions into the internet network [54] based on telecommunications. This evolution replies to the tendencies of the information society; the concept of a "homo virtualis" [55] appears to describe the connectivity of humans to networks [56], through mobile devices with the intellectual systems [57,58], allowing customers to access to cyber-space anywhere, any time.

The knowledge economy and the management of intellectual capital set the goals of the professionalisation of educational activities [57]. Digital technologies are broadly introduced into the learning process $[58,59]$, as cognitive research allows teachers to construct an open space for proactive interaction with students. This paper demonstrates that the introduction of new approaches and techniques is simultaneously accompanied by avoidance or ignorance as well as lack of motivation and interest from students.

These results lead to the following three options for further research: 
- Marketing issues oriented towards higher customer satisfaction and the construction of relationship marketing tools (communication with target audiences through social media, reputation management, and branding, etc.);

- Foresight research in the management of knowledge transfer for intellectual capital growth, taking into account that human resources are the exclusive producer of knowledge and play a unique role within value creation chains;

- Cognitive research to gain a deeper understanding of the processes of thinking, perception, and the basic processes of knowledge creation and assimilation by the students, treating learners as producers of their own original knowledge.

The new environment of saturated markets and post-modernity's multiple ideologies, where "people no longer accept normative responses to their demands for meaning" [47] (p. 109), requires universities to simultaneously meet economic needs (investing in intellectual capital) and to respond to the socio-cultural demand for sense, for the fundamental questions that reflect a deeply rooted search for the truth and an understanding of reality.

Thus, the diversity of views on the essence and economic nature of education leads to a variety of methods and concepts of knowledge management extended through marketing technologies. Knowledge marketing and management are interested in the further expansion of marketing techniques and the development of applied ideas to solving a variety of problems of both society and the state, as well as the emergence of new types of multidisciplinary knowledge. In this context, it seems correct to consider knowledge marketing and management as a technology. There is also a growing need for interdisciplinary cooperation within knowledge management between such modern sciences as neurobiology, psychology, pedagogy, and didactics to help answer important questions on consumer satisfaction in the context of educational services and the transmission of culture. Focusing on the consumer, as well as researching and analysing their emotional and cognitive needs, allows educators to "fine-tune" and update the design of educational programs in light of labor market needs and consumer requirements.

Author Contributions: Conceptualisation, N.N.P. and M.Y.A.; Investigation, N.N.P.; Methodology, D.A.F.; Validation, N.N.P.; Writing—original draft, N.N.P.; and Writing—review and editing, N.N.P. and M.Y.A.

Funding: The research was carried out with the financial support of the Russian Foundation for Basic Research in the framework of research project No. 16-29-12965/18.

Acknowledgments: The authors want to acknowledge the technical and organizational support given by the scientific collaborator Ilya Sergeevich Andronov, who helped greatly in the organization of the collecting data for the empirical part of this research.

Conflicts of Interest: The authors declare no conflict of interest.

\section{Appendix A The Questions Used in the Survey and Examined within the Research}

The respondents were asked to choose the most suitable answer according their own experience or to assess the question with the score from 1 to 10 , where 1 is the lowest mark and 10 is the highest evaluation.

Q1. What are the reasons listed below that influenced your choice of school? You can choose several answers by marking the pertinent cell. 


\begin{tabular}{|l|}
\hline Recommended by parents/friends/acquaintances. \\
\hline University ratings in the media. \\
\hline $\begin{array}{l}\text { I attended the open doors of various educational institutions/educational exhibitions; I have chosen this } \\
\text { institution as the one I liked. }\end{array}$ \\
\hline The opportunity to get a double diploma. \\
\hline Graduates of this university are demanded by leading enterprises. \\
\hline I live near the placement of the university/it provides a dormitory. \\
\hline Easier to enroll and study than in other universities. \\
\hline I was only accepted to this university. \\
\hline It has the lowest tuition fee. \\
\hline The main thing is to get a higher education, no matter what the university. \\
\hline There are guarantees of employment after graduation. \\
\hline
\end{tabular}

Q2-1. What is the reputation of educational institutions in the society?

a) Your university has a reputation as a prestigious $\quad 12345678910$ educational institution.

b) Your university has a reputation as an educational 12345678910 institution providing a high level of education.

c) Your university has a reputation as an educational 12345678910 institution with a good material and technical base and informational support.

d) Your university has a reputation as an educational 12345678910 institution with a highly professional teaching staff.

e) Your university has a reputation as an educational institution that provides good employment prospects.

Q2-2. How would you rate your university's conditions?

\begin{tabular}{|c|c|}
\hline $\begin{array}{l}\text { Hostels-availability and accessibility of } \\
\text { accommodation in a hostel. }\end{array}$ & 12345678910 \\
\hline Hostels-quality. & 12345678910 \\
\hline $\begin{array}{l}\text { Food in school-availability and accessibility of the } \\
\text { dining room. }\end{array}$ & 12345678910 \\
\hline School food-quality. & 12345678910 \\
\hline $\begin{array}{l}\text { Computers with Internet access and office } \\
\text { equipment—availability. }\end{array}$ & 12345678910 \\
\hline $\begin{array}{l}\text { Computers with Internet access and office } \\
\text { equipment—quality (novelty, modernity, power). }\end{array}$ & 12345678910 \\
\hline $\begin{array}{l}\text { Training/teaching and laboratory } \\
\text { buildings-availability (sufficiency, accessibility). }\end{array}$ & 12345678910 \\
\hline $\begin{array}{l}\text { Training/teaching and laboratory buildings-quality } \\
\text { (technical condition, freshness). }\end{array}$ & 12345678910 \\
\hline $\begin{array}{l}\text { Special equipment required for training (laboratory } \\
\text { and special equipment, training } \\
\text { simulators) - availability. }\end{array}$ & 12345678910 \\
\hline $\begin{array}{l}\text { Special equipment required for training (laboratory } \\
\text { and special equipment, training simulators)—quality } \\
\text { (novelty, modernity, and compliance with the } \\
\text { objectives of the educational process). }\end{array}$ & 12345678910 \\
\hline $\begin{array}{l}\text { Information resources (library, access to online } \\
\text { training resources)—availability. }\end{array}$ & 12345678910 \\
\hline $\begin{array}{l}\text { Information resources (library, access to online } \\
\text { resources on the subject of training)—accessibility } \\
\text { (ease of access, convenience of the library's working } \\
\text { hours, territorial accessibility). }\end{array}$ & 12345678910 \\
\hline Convenience of class schedules. & 12345678910 \\
\hline
\end{tabular}

Q2-3. How often does the educational process in your university use modern technical means and information technology training? 


\begin{tabular}{|l|l|}
\hline $\begin{array}{l}\text { Multimedia technology for lecturing, protection of } \\
\text { independent work. }\end{array}$ & 12345678910 \\
\hline Interactive whiteboards. & 12345678910 \\
\hline $\begin{array}{l}\text { Electronic versions of educational and scientific } \\
\text { literature. }\end{array}$ & 12345678910 \\
\hline Audiovisual materials (educational films). & 12345678910 \\
\hline Computer programs (tests, training, and simulators). & 12345678910 \\
\hline Internet access. & 12345678910 \\
\hline Social networks. & 12345678910 \\
\hline
\end{tabular}

Q2-4. How do you rate the atmosphere in your university?

\begin{tabular}{|l|l|}
\hline Friendly atmosphere, I feel comfortable. & 12345678910 \\
\hline $\begin{array}{l}\text { Neutral atmosphere, I do not feel comfortable visiting } \\
\text { my school, but there is no discomfort either. }\end{array}$ & 12345678910 \\
\hline $\begin{array}{l}\text { The atmosphere is tense, I am not comfortable in } \\
\text { school. }\end{array}$ & 12345678910 \\
\hline $\begin{array}{l}\text { Very bad atmosphere, I try to spend less time in my } \\
\text { school. }\end{array}$ & 12345678910 \\
\hline Hard to answer, as I do not pay attention. & 12345678910 \\
\hline
\end{tabular}

Q2-5. How would you assess the level of discrimination within your university?

The level of discrimination has concerned me. 12345678910

Q2-6. How would you rate the level of tolerance (tolerance) in your university?

My university is a tolerant environment. 12345678910

Q2-7. How would you rate the quality practices and internships in your university?

\begin{tabular}{|l|l|}
\hline $\begin{array}{l}\text { During training, many internships and practices of } \\
\text { various kinds are offered. }\end{array}$ & 12345678910 \\
\hline $\begin{array}{l}\text { Offered practices and internships are effective and } \\
\text { help the learning process. }\end{array}$ & 12345678910 \\
\hline Easy to get to practice/internship at a good business. & 12345678910 \\
\hline $\begin{array}{l}\text { Participating in internships and internships increases } \\
\text { my chances of getting a good job. }\end{array}$ & 12345678910 \\
\hline $\begin{array}{l}\text { The head of educational practice/internship quality } \\
\text { fulfilled their duties. }\end{array}$ & 12345678910 \\
\hline $\begin{array}{l}\text { Practice/internship helps to further employment in } \\
\text { the same company. }\end{array}$ & 12345678910 \\
\hline $\begin{array}{l}\text { I felt in demand at the enterprise during my } \\
\text { internship/internship. }\end{array}$ & 12345678910 \\
\hline $\begin{array}{l}\text { Practice/internship allows me to work out practical } \\
\text { skills. }\end{array}$ & 12345678910 \\
\hline Other. & 12345678910 \\
\hline
\end{tabular}

Q2-8. How is the place of practical internship determined at your university?

The student looks for a place of internship.

The university partially assists in the search for an internship.

The university provides practical specialist training in a student's specialty of choice.

Internship is not related to a student's future specialty.

It is possible both to choose the place of practical internship independently and to take advantage of offers

from the university.

Q3-1. How would you rate the quality of education in your university? 


\begin{tabular}{|l|l|}
\hline The knowledge gained is relevant and modern. & 12345678910 \\
\hline The knowledge gained is applicable in practice. & 12345678910 \\
\hline $\begin{array}{l}\text { Theoretical knowledge and practical skills are } \\
\text { sufficient in the educational process. }\end{array}$ & 12345678910 \\
\hline $\begin{array}{l}\text { I highly appreciate the professionalism of university } \\
\text { teachers. }\end{array}$ & 12345678910 \\
\hline Explanations of teachers are clear and accessible. & 12345678910 \\
\hline $\begin{array}{l}\text { Teachers are interested in the educational process and } \\
\text { are available for consultation. }\end{array}$ & 12345678910 \\
\hline $\begin{array}{l}\text { The educational process uses interactive forms of } \\
\text { learning (case analysis, business games, analysis of } \\
\text { real situations in practice, etc.). }\end{array}$ & 12345678910 \\
\hline The educational process is rich and interesting. & 12345678910 \\
\hline $\begin{array}{l}\text { There is intensive communication on the Internet and } \\
\text { the development of digital technologies. }\end{array}$ & 12345678910 \\
\hline
\end{tabular}

Q3-2. How would you rate the learning results of your university?

\begin{tabular}{|c|c|}
\hline $\begin{array}{l}\text { I feel that I have good professional knowledge and } \\
\text { skills. }\end{array}$ & 12345678910 \\
\hline $\begin{array}{l}\text { I developed personal qualities necessary for work } \\
\text { (responsibility, ability to make decisions } \\
\text { independently, communication skills, ability to work } \\
\text { in a team, etc.). }\end{array}$ & 12345678910 \\
\hline I feel I can compete in the Russian labor market. & 12345678910 \\
\hline I feel I can compete in the global labor market. & 12345678910 \\
\hline \multicolumn{2}{|l|}{ Q3-3. What are your employment prospects? } \\
\hline $\begin{array}{l}\text { After graduation, I will be able to quickly find a job in } \\
\text { my specialty. }\end{array}$ & 12345678910 \\
\hline $\begin{array}{l}\text { After graduation, I will be able to find an interesting } \\
\text { job in my specialty. }\end{array}$ & 12345678910 \\
\hline $\begin{array}{l}\text { After graduation, I will be able to find a decently paid } \\
\text { job in my specialty. }\end{array}$ & 12345678910 \\
\hline $\begin{array}{l}\text { After graduation, I will be able to find a job at a } \\
\text { company where I had an internship. }\end{array}$ & 12345678910 \\
\hline Having a higher education gives me stability in life. & 12345678910 \\
\hline $\begin{array}{l}\text { The presence of higher education provides an } \\
\text { opportunity to find a job in the leading companies of } \\
\text { the country and the world. }\end{array}$ & 12345678910 \\
\hline
\end{tabular}

Q4-1 Do you attend lectures of invited teachers, representatives from employers, well-known media people, thematic conferences, exhibitions, master's classes, and job fairs in your school?

The university regularly organizes such events.

Such events happen, but rarely.

We have no such events.

I am not interested in this information.

Q4-2 Which of the additional educational activities would be the most interesting to you (you can choose several answers)?

\begin{tabular}{|l|}
\hline Lectures of specialists in my profession. \\
\hline Scientific and practical conferences and exhibitions. \\
\hline Workshops from professionals. \\
\hline Student work contests. \\
\hline Excursions to enterprises. \\
\hline Exchange training at a vocational school abroad. \\
\hline Job fairs. \\
\hline Practices and internships abroad. \\
\hline Art clubs, sports clubs. \\
\hline Other. \\
\hline
\end{tabular}


Q4-3. In which international activities of the university did you participate in the learning process/what international activities related to you?

\begin{tabular}{|c|c|}
\hline $\begin{array}{l}\text { Foreign teachers are invited to give courses at the } \\
\text { university. }\end{array}$ & 12345678910 \\
\hline Students are sent to study at foreign universities. & 12345678910 \\
\hline $\begin{array}{l}\text { The presence of disciplines taught in a foreign } \\
\text { language. }\end{array}$ & 12345678910 \\
\hline $\begin{array}{l}\text { Availability of double degree programs with foreign } \\
\text { universities. }\end{array}$ & 12345678910 \\
\hline $\begin{array}{l}\text { Accounting for the academic load in the European } \\
\text { system of academic credits and issuance at the } \\
\text { university of the European Diploma Supplement. }\end{array}$ & 12345678910 \\
\hline Practice/internship abroad. & 12345678910 \\
\hline Study visits to universities and enterprises abroad. & 12345678910 \\
\hline $\begin{array}{l}\text { The university provides the opportunity for } \\
\text { international exchanges, but it is impossible to get } \\
\text { there. }\end{array}$ & 12345678910 \\
\hline There is no international activity. & 12345678910 \\
\hline \multicolumn{2}{|c|}{ Q4-4. Are you interested in the international activities of your university? } \\
\hline \multicolumn{2}{|l|}{ Yes, of course, they affect the level of my education. } \\
\hline \multicolumn{2}{|l|}{ I do not know, I am not sure if I need them. } \\
\hline \multicolumn{2}{|c|}{ No, I do not want to participate in the international activities of the university. } \\
\hline \multicolumn{2}{|c|}{ Q4-5. How is employment assistance for graduates organized in your university? } \\
\hline \multicolumn{2}{|c|}{ My university provides help through its Employment Center. } \\
\hline \multicolumn{2}{|l|}{ The university regularly holds job fairs. } \\
\hline \multicolumn{2}{|c|}{ Orders for "specialists" come from employers to the university come "orders". } \\
\hline \multicolumn{2}{|c|}{ The university does not provide assistance in finding employment. } \\
\hline I do not know. & \\
\hline
\end{tabular}

\section{References}

1. Nahapiet, J.; Ghoshal, S. Social capital, intellectual capital and the organizational advantage. Acad. Manag. Rev. 1998, 23, 242-266. [CrossRef]

2. Schultz, T.W. Investment in human capital, Presidential address before the American Economic Association. Am. Econ. Rev. 1961, 51, 1-17.

3. Becker, G.S. Human Capital: A Theoretical and Empirical Analysis with Special Reference to Education; NBER, University of Chicago Press: Chicago, IL, USA, 1964.

4. Sveiby, K.E. Intellectual Capital: Thinking Ahead; Australian CPA: Melbourne, Australia, 1998; pp. 18-22.

5. Żelazny, R. Information society and knowledge economy-Essence and key relationships. J. Econ. Manag. 2015, 20, 5-22.

6. Cricelli, L.; Greco, M.; Grimaldi, M.; Llanes Dueñas, P. Intellectual Capital and University Performance in Emerging Countries: Evidence from Colombian Public Universities. J. Intellect. Cap. 2018, 19, 71-95. [CrossRef]

7. Necheukhina, N.S.; Matveeva, V.S.; Babkin, I.A.; Makarova, E.N. Modern approaches to the educational process aimed at improving the quality of highly qualified personnel training. In Proceedings of the 2017 IEEE VI Forum Strategic Partnership of Universities and Enterprises of Hi-Tech Branches (Science. Education. Innovations) (SPUE), St. Petersburg, Russian, 15-17 November 2017; Shaposhnikov, S., Ed.; IEEE: Piscataway, NJ, USA, 2017; pp. 192-195.

8. Pokrovskaia, N.N.; Petrov, M.A.; Gridneva, M.A. Diagnostics of Professional Competencies and Motivation of the Engineer in the Knowledge Economy. In Proceedings of the 2018 Third International Conference on Human Factors in Complex Technical Systems and Environments and Environments (ERGO), St. Petersburg, Russian, 4-7 July 2018; pp. 28-31. 
9. Razinkina, E.; Pankova, L.; Trostinskaya, I.; Pozdeeva, E.; Evseeva, L.; Tanova, A. Student satisfaction as an element of education quality monitoring in innovative higher education institution. In E3S Web of Conferences; EDP Science: Les Ulis, France, 2018; Volume 33, p. 03043. [CrossRef]

10. Glukhov, V.V.; Vasetskaya, N.O. Improving the teaching quality with a smart-education system. In Proceedings of the 2017 IEEE VI Forum Strategic Partnership of Universities and Enterprises of Hi-Tech Branches (Science. Education. Innovations) (SPUE), St. Petersburg, Russian, 15-17 November 2017; Shaposhnikov, S., Ed.; IEEE: Piscataway, NJ, USA, 2017; pp. 17-21.

11. Krasnov, S.V.; Kalmykova, S.V.; Abushova, E.E.; Krasnov, A.S. Problems of Quality of Education in the Implementation of Online Courses in the Educational Process. In Proceedings of the 2018 International Conference on High Technology for Sustainable Development (HiTech), Sofia, Bulgaria, 11-14 June 2018.

12. Hong, J.-C.; Hwang, M.-Y.; Tai, K.-H.; Lin, P.-H. Intrinsic motivation of Chinese learning in predicting online learning self-efficacy and flow experience relevant to students' learning progress. Comput. Assist. Lang. Learn. 2017, 30, 552-574. [CrossRef]

13. Bylieva, D.S.; Lobatyuk, V.V.; Nam, T.A. Academic Dishonesty in e-Learning System. In Proceedings of the 33rd International Business Information Management Association Conference, Granada, Spain, 10-11 April 2019; Soliman, K.S., Ed.; IBIMA: King of Prussia, PA, USA, 2019.

14. Al Musawi, A.S. Use of social media in technology-enhanced learning. In Transforming Education in the Gulf Region: Emerging Learning Technologies and Innovative Pedagogy for the 21st Century; Alshahrani, K., Ally, M., Eds.; Taylor and Francis: Milton Park, Didcot, UK; Abingdon, UK, 2016; pp. 126-138.

15. Andreev, A.V.; Burlov, V.G.; Gomazov, F.A.; Penner, Y.A. Improving the System of Higher Education for Enterprises of Industrial and Economic Complex. In Proceedings of the 2018 XVII Russian Scientific and Practical Conference on Planning and Teaching Engineering Staff for the Industrial and Economic Complex of the Region (PTES), St. Petersburg, Russian, 14-15 November 2018; pp. 86-88.

16. Shipunova, O.D.; Mureyko, L.V.; Berezovskaya, I.P.; Kolomeyzev, I.V.; Serkova, V.A. Cultural code in controlling stereotypes of mass consciousness. ERSJ 2017, 20, 694-705.

17. Aristotle. Nicomachean Ethics; Broadie, S., Rowe, C., Eds.; Oxford University Press: Oxford, UK, 2002.

18. Ferrari, M.; Kahn, A.; Benayon, M.; Nero, J. Phronesis, Sophia, and Hochma: Developing Wisdom in Islam and Judaism. Res. Hum. Dev. 2011, 8, 128-148. [CrossRef]

19. Souter, R.W. Prolegomena to Relativity Economics; Columbia University Press: New York, NY, USA, 1933.

20. Stigler, G.J. Economics-The Imperial Science? Scand. J. Econ. 1984, 86, 301-313. [CrossRef]

21. Boulding, K.E. Economics as a Moral Science. Am. Econ. Rev. 1969, 59, 1-12.

22. Sánchez-Torres, J.M.; Rivera-Torres, S.C. A model for measuring research capacity using an intellectual capital-based approach in a Colombian higher education institution. Innovar 2009, 19, 179-197.

23. Sánchez, M.P.; Elena, S. Intellectual capital in universities: Improving transparency and internal management. J. Intellect. Cap. 2006, 7, 529-548. [CrossRef]

24. Sánchez, M.P.; Elena, S.; Castrillo, R. Intellectual capital dynamics in universities: A reporting model. J. Intellect. Cap. 2009, 10, 307-324. [CrossRef]

25. Secundo, G.; Dumay, J.; Schiuma, G.; Passiante, G. Managing intellectual capital through a collective intelligence approach: An integrated framework for universities. J. Intellect. Cap. 2016, 17, $298-319$. [CrossRef]

26. Feng, H.I.; Chen, C.S.; Wang, C.H.; Chiang, H.C. The role of intellectual capital and university technology transfer offices in university-based technology transfer. Serv. Ind. J. 2012, 32, 899-917. [CrossRef]

27. Lowe, C.U. The Triple Helix-NIH, Industry, and the Academic World. Yale J. Biol. Med. 1982, 55, $239-246$. [PubMed]

28. Etzkowitz, H.; Leydesdorff, L. The Triple Helix-University-Industry-Government Relations: A Laboratory for Knowledge Based Economic Development. EASST Rev. 1995, 14, 14-19.

29. Bontis, N. There's a price on your head: Managing intellectual capital strategically. In Business Quarterly; University of Western Ontario: London, ON, Canada, 1996; Volume 60, pp. 40-47.

30. Edvinsson, L.; Malone, M.S. Intellectual Capital: Realizing Your Company's True Value by Finding its Hidden Brainpower; Harper Business: New York, NY, USA, 1997.

31. Stewart, T.A. Intellectual Capital: The New Wealth of Organizations; Doubleday: New York, NY, USA, 1997.

32. Perez, S.E.; Martinaitis, Ž.; Leitner, K.H. An intellectual capital maturity model (ICMM) to improve strategic management in European universities: A dynamic approach. J. Intellect. Cap. 2015, 16, 419-442. [CrossRef] 
33. Yang, J.-T. Knowledge sharing: Investigating appropriate leadership roles and collaborative culture. Tour. Manag. 2007, 28, 530-543. [CrossRef]

34. Williamson, O.E. Economic Institutions of Capitalism; Free Press: New York, NY, USA, 1985.

35. Roos, J.; Roos, G.; Dragonetti, N.C.; Edvinsson, L. Intellectual Capital: Navigating the New Business Landscape; Macmillan Press: London, UK, 1997.

36. Kok, A. Intellectual Capital Management as Part of Knowledge Management Initiatives at Institutions of Higher Learning. Electron. J. Knowl. Manag. 2007, 5, 181-192.

37. Saint-Onge, H. Tacit knowledge: The key to strategic alignment of intellectual capital. Strategy Leadersh. 1996, 24, 10-14. [CrossRef]

38. Timermanis, E.; Ivanov, S.; Zamorev, A.; Smaragdina, A. Transformation of the postmodern ontology. In Proceedings of the 4th International Multidisciplinary Scientific Conference on Social Sciences and Arts SGEM2017, Albena, Bulgaria, 22-31 August 2017; Pletnev, V., Ed.; STEF92 Technology: Sofia, Bulgaria, 2017; Volume 1, pp. 117-124. [CrossRef]

39. Goldberg, A.E. Bespredel and the Conduct of Russian "Hybrid Operations". Small Wars J. 26 October 2016. Available online: http://smallwarsjournal.com/jrnl/art/bespredel-and-the-conduct-of-russian-hybridoperations $\backslash$ T1 $\backslash$ textquotedblright (accessed on 20 May 2019).

40. Mikheev, A. Five Russian Words That Don't Exist in English but Should; Russia Beyond the Headlines: Moscow, Russia, 2017.

41. Bock, G.-W.; Zmud, R.W.; Kim, Y.-G.; Lee, J.-N. Behavioral intention formation in knowledge sharing: Examining the rules of extrinsic motivators, social-psychological forces, and organizational climate. MIS Q. 2005, 29, 87-111. [CrossRef]

42. Pratt, D.D.; Kelly, M.; Wong, W.S.S. Chinese Conceptions of 'Effective Teaching' in Hong Kong: Towards Culturally Sensitive Evaluation of Teaching. Int. J. Lifelong Educ. 1999, 18, 241-258. [CrossRef]

43. Hess, R.D.; Azuma, M. Cultural support for schooling: Contrasts between Japan and the United States. Educ. Res. 1991, 20, 2-8. [CrossRef]

44. Lulat, Y.G.-M. A History of African Higher Education from Antiquity to the Present: A Critical Synthesis Studies in Higher Education; Greenwood Publishing Group: Westport, CT, USA, 2005.

45. Durkheim, E. Les Formes Elémentaires de la Vie Religieuse: Le Système Totémique en Australie, [the Elementary Forms of Religious Life]; Librairie Félix Alcan: Paris, France, 1912. (In French)

46. Durkheim, E. The Elementary Forms of Religious Life; Free Press: New York, NY, USA, 1995.

47. Cova, V.; Bousquet, J.; Claveau, C.; Shabir, Q.A. The changing dichotomy between the sacred and the profane: A historical analysis of the Santiago de Compostela pilgrimage. J. Manag. Spiritual. Relig. 2019, 16, 109-130. [CrossRef]

48. Rudskoy, A.I.; Borovkov, A.I.; Romanov, P.I. Russian experience in engineering education development. Vyss. Obraz. Ross. 2018, 27, 151-162.

49. Wipf, A. (Ed.) Professional higher education 4.0: A change for universities of applied sciences. In Proceedings of the 27th Conference, Le Havre, France, 30-31 March 2017; EURASHE: Brussels, Belgium, 2017.

50. Sombart, W. Krieg und Kapitalismus; Duncker \& Humblot: Leipzig, Germany, 1913.

51. Beck, U.; Giddens, A.; Lash, S. Reflexive Modernization. Politics, Tradition and Aesthetics in the Modern Social Order; Polity Press: Cambridge, UK, 1994.

52. Bylieva, D.; Lobatyuk, V.; Rubtsova, A. Smartmob: Evolution from flashmob to smartcity element. In RPTSS 2017 International Conference on Research Paradigms Transformation in Social Sciences. Eur. Proc. Soc. Behav. Sci. EpSBS 2017, XXXV, 225-235. [CrossRef]

53. Evseeva, L.I.; Obukhova, J.O.; Tanova, A.G. Network technologies and the new perception of communication. In Proceedings of the 4th International Multidisciplinary Scientific Conference on Social Sciences and Arts. SGEM2017, Albena, Bulgaria, 22-31 August 2017; Pletnev, V., Ed.; STEF92 Technology: Sofia, Bulgaria, 2017; Volume 1, pp. 57-64. [CrossRef]

54. Pokrovskaia, N.N.; Khansuvarova, T.A.; Khansuvarov, R.A. Network decentralized regulation with the fog-edge computing and blockchain for business development. In Proceedings of the 14th European Conference on Management, Leadership and Governance ECMLG 2018, Utrecht, The Netherlands, 18-19 October 2018; de Waal, B.M.E., Ravesteijn, P., Eds.; Academic Conferences and Publishing International Limited: Reading, UK, 2018; pp. 205-212. 
55. Golohvastov, D.V.; Pokrovskaia, N.N.; Snisarenko, S.O. Institutional Confidence and Economic Intelligence for the Performance at Macro and Micro Networks. In Proceedings of the 4th International Conference on Management, Leadership and Governance ICMLG 2016, St Petersburg, Russia, 14-15 April 2016; Academic Conferences and Publishing International Limited: Reading, UK, 2016; pp. 255-263.

56. Almazova, N.I.; Kostina, E.A.; Khalyapina, L.P. The new position of foreign language as education for global citizenship. Novosib. State Pedagog. Univ. Bull. 2016, 6, 7-17. [CrossRef]

57. Trostinskaia, I.R.; Safonova, A.S.; Pokrovskaia, N.N. Professionalization of education within the digital economy and communicative competencies. In Proceedings of the 2017 IEEE VI Forum Strategic Partnership of Universities and Enterprises of Hi-Tech Branches (Science. Education. Innovations), St Petersburg, Russia, 15-17 November 2017; Shestopalov, M., Ed.; Saint Petersburg Electrotechnical University "LETI": St. Petersburg, Russia, 2017; pp. 29-32. [CrossRef]

58. Piskun, O.E.; Ababkova, M.Yu.; Leontieva, V.L. Biological feedback method to facilitate academic progress. Teor. Prakt. Fiz. Kult. 2018, 10, 45-47.

59. Ababkova, M.Yu.; Leontieva, V.L. Neuromarketing for education: Rethinking frameworks for marketing activities. Eur. Proc. Soc. Behav. Sci. EpSBS 2018, XXXV, 1-9. [CrossRef]

(C) 2019 by the authors. Licensee MDPI, Basel, Switzerland. This article is an open access article distributed under the terms and conditions of the Creative Commons Attribution (CC BY) license (http://creativecommons.org/licenses/by/4.0/). 